\title{
Epidemiological Investigation, Serotypes and Distribution of Verocytotoxigenic Escherichia coli(VTEC) in Raw Milk and Milk Products in Uyo, Nigeria
}

\author{
*Akinjogunla, O.J., Akaka B. C. and Inyang, C.U. \\ Department of Microbiology, Faculty of Science, University of Uyo, P.M.B. 1017, Uyo, \\ Akwa Ibom State.
}

\begin{abstract}
Food borne diseases are of great concern globally especially in the developing countries where poor sanitation is applied during collection and processing of milk from animals. The epidemiological investigation, serotypes and distribution of verocytotoxin (VTI and VT2)producing Escherichia coli in raw milk and milk products were determined using structured questionnaire, Cefixime tellurite-sorbitol MacConkey agar, agglutination kits and VTECRPLA Toxin detection Kit. Out of 27 milkers, $7.4 \%$ had primary education, $22.2 \%$ washed the milk utensils with cold water and soap, $11.1 \%$ washed their hands before milking, while $7.4 \%$ milkers washed the udder of the animals before milking. All the yoghurts had the product names; $85.7 \%$ had NAFDAC numbers; $80.0 \%$ had Batch Numbers, while $71.4 \%$ had Manufacturer $s^{\prime}$ Addresses. The unpasteurized milk samples had E. coli 0157 and non $0157 E$. colicounts (CFU.ml ${ }^{-1}$ ) ranging from $4.0 \times 10^{2}$ to $1.7 \times 10^{3}$ and $6.0 \times 10^{2}$ to $2.0 \times 10^{3}$, respectively, while $E$. coli 0157 and non 0157 E. coli counts of milk products were between $1.0 \times 10^{2}$ and $1.0 \times 10^{3} \mathrm{CFU} \mathrm{ml}^{-1}$. E. coli 0157 had the highest percentage occurrence (38.3\%), while E. coli 0145 had the lowest percentage occurrence $(2.1 \%)$. More than $38.3 \%$ of the $E$. coli serotypes produced VT2, while $\geq 12.8 \%$ were VT1 producers. The occurrence of VTEC in the unpasteurized milk shows that the milkers should be enlightened on the necessary sanitary practices to adopt during milking and also post-pasteurization contamination of milk products should be avoided.
\end{abstract}

Key Words: Verotoxigenic, Escherichia coli, Milk, Yoghurt, Nono, Serotypes.

*Corresponding Author's E-mail/Phone No: papajyde2000@yahoo.com/08064069404

\section{Introduction}

Verocytotoxigenic Escherichia coli (VTEC) or Shigatoxigenic Escherichia coli (STEC) are rod shaped, Gram negative, facultative anaerobe, lactose fermenter and non-endospore forming pathogens of animals and humans (Dwight et al., 2004; Akinjogunla et al., 2009). These enteric pathogens with an estimated infectious dose of $<50$ organisms are regarded as the most common food-borne zoonotic pathogens causing several disease conditions in humans (Tilden et al., 1996; Kumar et al., 2014). The serotype of a VTEC is based on the ' $O$ ' antigen determined by the polysaccharide portion of cell wall lipopolysaccharide and the ' $\mathrm{H}$ ' antigen by the flagella protein (Griffin and Tauxe, 1991).

Ruminants are considered an important source of VTEC with cattle being regarded as the 
primary reservoir (Blanco et al., 1996; Perera et al., 2015). In some countries, direct consumption of raw milk is much frequent and more popular than consumption of pasteurized milk and milk products (yoghurt and nono) for it is presumed especially by the rural populace, that raw milk and its by-products have nutritional advantages over the pasteurized milk (Altalhi and Hassan, 2009). Although milk is an extremely nutritious food, it can likewise serve as an excellent growth medium for a broad range of microorganisms such as $E$. coli. Fresh raw milk obtained from a healthy animal normally contained a microbial load $\left(<10^{3}\right.$ $\mathrm{CFU} / \mathrm{ml}$ ), but the microbial load might increase up to 100 times fold if stored for some time at normal temperature (Pitkala et al., 2004). Inadequate cooling of milk, improper udder preparation methods, unhygienic milking equipment and water used for cleaning purposes are considered as the sources of milk contamination (Harding, 1995; Altalhi and Hassan, 2009).

Humans may acquire STEC/VTEC infections primarily from consumption of undercooked beef, raw milk, meat, dairy products, unpasteurized fruit juices and water contaminated with faeces of animals (Nataro and Kaper, 1998; Kumar et al., 2014). Food borne diseases are of great concern around the world in the developing countries where poor sanitation is applied during collection and processing of milk from cattle, cows, goats and buffaloes. Verocytotoxigenic $E$. coli (VTEC) 0157 is a predominant cause of haemorrhagic colitis ( $\mathrm{HC}$ ) and haemolytic uraemic syndrome (HUS) in humans worldwide (Adwan et al., 2002; Borgattaa et al., 2012). The non- 0157 E. coli serotypes which have emerged as a significant cause of human diseases are E. coli 026, 0111, 0121, 045 and 0145 (Tarr and Neil, 1996) and some of them are linked to cattle (Blanco et al., 1997).

Production of verocytotoxin (VT) is the major determinant of the virulence of $E$. coli serotypes and two major types of VT (VT1 and VT2) have been recognized (Paton and Paton, 1998). These two toxins are genetically and immunologically distinct with only about 55 to $60 \%$ genetic and amino acid sequence relatedness (Lee et al., 2007). The verocytotoxins inhibit cellular protein synthesis, leading to death of the affected cells (Paton and Paton, 1998). The toxins have a profound effect on the endothelial cells of blood vessels, thus causing endothelial damage (Paton and Paton, 1998). Consequently, this study aimed at determining the serotypes and distribution of VTEC in raw milk and milk products in Uyo, Nigeria

\section{Materials and Methods}

\section{Collection of Samples}

The cow milk $(n=29)$ and goat milk $(n=47)$ samples were collected directly from cows and goats using sterile, wide-mouth sample containers by the Hausa / Fulani cattle rearers residing in Uyo, while nono $(n=42)$ and yoghurt $(n=35)$ samples were purchased from the hawkers. All the samples were properly labelled, immediately kept in ice packed flask $\left(4^{\circ} \mathrm{C}\right)$ and transported to Microbiology Department, University of Uyo, for bacteriological analysis.

\section{Epidemiological Investigation}

An epidemiological investigation was conducted using a well-structured questionnaire to obtain information on the hygienic milking practices by milkers (respondents) such as milk utensils used for milking, cleaning frequency of milk utensils, washing of milk utensils, hand washing by the milkers, udder washing and towel used for udder drying. The information on the sociodemographic characteristics of the milkers was also obtained.

Isolation of E. coli 0157 and Non- 0157 E. coli from Raw Milk and Milk Products

One (1) $\mathrm{ml}$ of each serially diluted raw milk and milk products was inoculated onto each plate of Sorbitol MacConkey agar supplemented with Cefixime Tellurite in triplicates and incubated aerobically overnight at $37^{\circ} \mathrm{C}$. After incubation, a loopful of each colourless colony (presumptive E. coli 0157) and pink colony (presumptive non0157 E. col/) obtained was streaked onto Eosin Methylene Blue (EMB) agar plates and aerobically incubated overnight at $37^{\circ} \mathrm{C}$. The greenish metallic sheen colonies on EMB plates were streaked onto nutrient agar slants and incubated overnight at $37^{\circ} \mathrm{C}$. The morphological and biochemical identifications of the $E$. coli were carried out using conventional methods (Cheesbrough, 2006).

Serological Identification of E. coli 0157 and NonO157 E. coli 
The presumptive colonies of E. coli $\mathrm{O} 157$ were serologically confirmed using Dry Spot E. coli O157 latex agglutination test kits (Oxoid, UK), while the non - 0157 E. coli serotypes: 026, 0125, 0103, 0111, 0128 and 0145 were determined using the Dryspot $E$. coli Seroscreen Latex Test Kits (Oxoid, UK). Each E. coli (24-hr old) was emulsified in a drop of sterile normal saline / phosphate buffered saline on the small circle at the base of the test ring reaction area. The suspension was well mixed using a loop and placed onto the circle on the appropriate test card. The test card was gently hand rocked and observed for agglutination within 1-2 mins. Agglutination indicated positive reaction and identified the $E$. coli serotypes.

\section{Detection of Verocytotoxins Producing E. coli Serotypes}

The production of verocytotoxins (VT1 and VT2) by $E$. coli serotypes was detected using a VTECRPLA Toxin detection Kit (Oxoid, TD0960A). Each $E$. coli was inoculated onto each plate of Brain Heart Infusion Agar slope $(10 \mathrm{ml})$ and incubated at $37^{\circ} \mathrm{C}$ for $18 \mathrm{hrs}$. After incubation, a loopful of each colony was suspended in $0.85 \% \mathrm{NaCl}$ solution (1ml) containing polymyxin $B$ and incubated for 30 mins at $37^{\circ} \mathrm{C}$. The suspension was centrifuged at 4,000 rpm for 20 mins and the supernatant was collected for the assay. A $25 \mu \mathrm{L}$ of diluent was dispensed into 24 wells in three rows of V-bottom micro-titre plate. With $25 \mu \mathrm{L}$ of the supernatant obtained above, a 1:2 serial dilution was made in each row from the first well to the seventh. The eight (last) well was left containing only the diluents. Thereafter, $25 \mu \mathrm{L}$ of latex VT2 was added to all the eight wells in the second row and $25 \mu \mathrm{l}$ latex control was added to all the eight wells in the third row. The micro-titre plate was covered with a lid, left undisturbed on a vibration-free surface at room temperature for $20 \mathrm{hrs}$, then the contents of each well were mixed by agitating using hand ; each well was examined for agglutination against a black background.

\section{Results}

The socio-demographic characteristics of the milkers (respondents) are presented in Table 1. Of the 27 milkers, 19 (70.4\%) were males, while $8(29.6 \%)$ were females; $16(59.3 \%)$ of the milkers did not know their ages, while 11 milkers were within $\leq 20 \mathrm{yrs}$ and $\geq 51 \mathrm{yrs}$. Twenty three (23) milkers had no formal education, 2 (7.4\%) attended primary education, 2 (7.4\%) attended secondary education, while none had university education. Fifteen (55.6\%) milkers were employed as herders, while 12 (44.4\%) owned the cows / goats (Table 1). The results showed that $33.3 \%$ milkers used plastic cups and plates for collection of milk from the cows and goats, while $59.3 \%$ milkers used plastic bottles only (Figs 1 and 2). All the milkers ( $n=27$ ) cleaned the milk utensils; $22.2 \%$ milkers washed the milk utensils with cold water and soap, while $77.8 \%$ milkers washed the milk utensils with cold water only. Of the 27 milkers, $11.1 \%$ washed their hands before milking, $37.0 \%$ washed their hands after milking, and $51.9 \%$ milkers did not wash their hands. Only two (2) milkers washed the udder of the animals before milking and also cleaned the udder with a towel (Table 2).

The records of the physical examination of packaged yoghurts are presented in Table 3. Of the 35 milk products (yoghurts) collected, 25 $(71.4 \%), 33(94.3 \%)$ and $30(85.7 \%)$ had NAFDAC numbers, production dates and expiry dates, respectively. All the yoghurts had the product's names; $80.0 \%$ had Batch Numbers, $71.4 \%$ had Manufacturer's Addresses, while 94.3 $\%$ had the Volumes of their Contents (yoghurt) written on the packages (Table 3 ).

The results of the $E$ coli 0157 and non- $0157 E$ coli loads of the raw milk and milk products are presented in Table 4. The cow milk had the minimum E coli 0157 count of $4.0 \times 10^{2} \mathrm{CFU} / \mathrm{ml}$ and maximum $E$ coli 0157 count of $1.7 \times 10^{3}$ $\mathrm{CFU} / \mathrm{ml}$; the goat milk had the minimum $E$ coli 0157 count of $5.0 \times 10^{2} \mathrm{CFU} / \mathrm{ml}$ and maximum E coli 0157 count of $1.2 \times 10^{3} \mathrm{CFU} / \mathrm{ml}$, the nono had the minimum $E$ coli 0157 count of $1.0 \times 10^{2}$ $\mathrm{CFU} / \mathrm{ml}$ and maximum $E$ coli 0157 count of $7.0 \mathrm{x}$ $10^{3} \mathrm{CFU} / \mathrm{ml}$, while the yoghurts had the minimum $E$ coli 0157 count of $1.0 \times 10^{2} \mathrm{CFU} / \mathrm{ml}$ and maximum $E$ coli 0157 count of $5.0 \times 10^{3} \mathrm{CFU} / \mathrm{ml}$ 
(Table 4). The goat milk had the highest mean (mm \pm S.D) non 0157 E colicount of $1.1 \pm 1.0$ $\mathrm{x} 10^{3} \mathrm{CFU} / \mathrm{ml}$, followed by cow milk with $9.0 \pm 4.8$ $\mathrm{x} 10^{2} \mathrm{CFU} / \mathrm{ml}$, nono with $5.7 \pm 2.5 \times 10^{2} \mathrm{CFU} / \mathrm{ml}$, while yoghurts had the lowest mean $(\mathrm{mm} \pm \mathrm{S} . \mathrm{D})$ non 0157 E colicount of $3.8 \pm 2.8 \times 10^{3} \mathrm{CFU} / \mathrm{ml}$ (Table 4). The occurrences of $59 E$. coli isolated from the raw milks and milk products are as follows: $13 / 29$ (44.8 \%) from cow milk; $22 / 47$ $(46.8 \%)$ from goat milk; $15 / 42$ (35.7\%) from nono, while $9 / 35(25.7 \%)$ were obtained from yoghurts (Table 5). Out of the fifty-nine (59) $E$. coli isolates from the raw milk and milk products, $47(99.7 \%)$ were typable $E$. coli, while 12 (20.3\%) were non- typable E. coli. The highest number of typable $E$. coli $(n=19)$ was obtained from the goat milk, followed by cow milk with $\mathrm{n}=11$, nono had $\mathrm{n}=11$ typable $E$. coli, while the typable $E$. coli obtained from yoghurts was $\mathrm{n}=6$ (Table 7).

Out of the 47 E. coliserotypes obtained, E. coli 0157 had the highest percentage occurrence (38.3\%), followed by E. coli 0125 (19.1\%), while $E$. coli 0145 had the lowest percentage occurrence $(2.1 \%)$. The percentage occurrence of E. coli 0111, E. coli 026, E. coli 0103 and E. coli 0128 from the raw milk and milk products was 8.5 $\%, 14.9 \%, 12.8 \%$ and $4.3 \%$, respectively (Table 5). Out of the 47 E. coliserotypes, $12.8 \%$ $E$. coli serotypes produced only verocytotoxin $\mathrm{VT} 1,38.3 \%$ E. coli serotypes produced only verocytotoxin $\mathrm{VT} 2$, while $14.8 \% E$. coli serotypes were both verocytotoxin VT1 and VT2 producers (Table 6). There was no statistically significant difference between the verocytotoxin- and nonverocytotoxin- producing $E$. coli serotypes (p: $0.81 ; \times 2: 2.99)$.

Table 1: Socio-demographic Characteristics of Milkers (Respondents)

\begin{tabular}{ccc}
\hline $\begin{array}{c}\text { Demographic } \\
\text { Information }\end{array}$ & Categories & No (\%) of \\
Gender & Male & $19(70.4)$ \\
& Female & $8(29.6)$ \\
\hline & $\leq 20$ & $3(11.1)$ \\
Age (yrs) & $21-30$ & $5(18.5)$ \\
& $31-40$ & $2(7.4)$ \\
& $41-50$ & $1(3.7)$ \\
& $\geq 51$ & $0(0.0)$ \\
& Don't Know & $16(59.3)$ \\
\hline Level of Education & No Formal Educ. & $23(85.2)$ \\
& Primary School & $2(7.4)$ \\
& Secondary School & $2(7.4)$ \\
Ownership of & Tertiary Institution & $0(0.0)$ \\
Cow/Goat & Owner / Herding & $12(44.4)$ \\
& Employed as Herder & $15(55.6)$ \\
\cline { 2 - 3 }
\end{tabular}

Table 2: Milking Containers Used and Sanitary Practices of Milkers (Respondents)

\begin{tabular}{ccc}
\hline & \multicolumn{2}{c}{ Responses of Milkers } \\
Variables & Number & Percentage \\
\hline
\end{tabular}

Milk utensils used for milking 
(a) Plastic cup / plate

(b) Plastic bottles

(c) Others

Cleaning Frequency of milk utensils

(a) Before every use

(b) After every use

(c) Before and after use

Washing of milk utensils

(a) Cold water and soap

(b) Water only

(c) Warm water and Soap

Hand washing by the milkers

(a) Before milking

(b) After milking

(c) No washing

Udder washing

(a) Before milking

(b) No washing

Towel Used for Udder Drying

(a) Common towel

(b) Just with hand

(c) No washing and drying
9

16

2

5

9

13

6

21

0

3

10

14

2

25
33.3

59.3

7.4

18.5

33.3

48.1

22.2

77.8

0.0

11.1

37.0

51.9

7.4

92.6

$0 \quad 0.0$

$2 \quad 7.4$

$25 \quad 92.6$

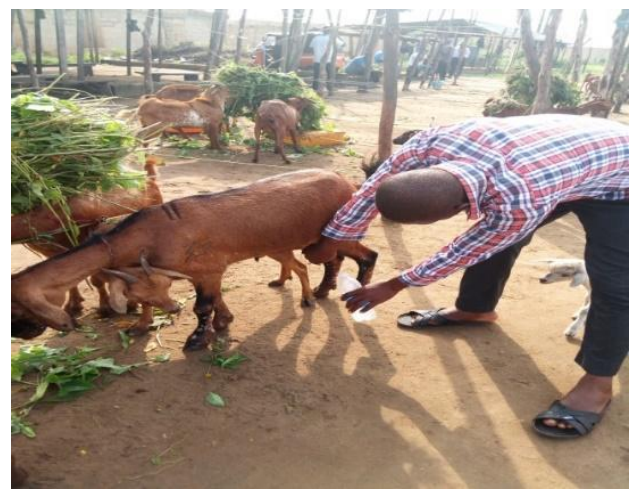

Fig 1: Collection of goat milk using plastic bottle by a milker

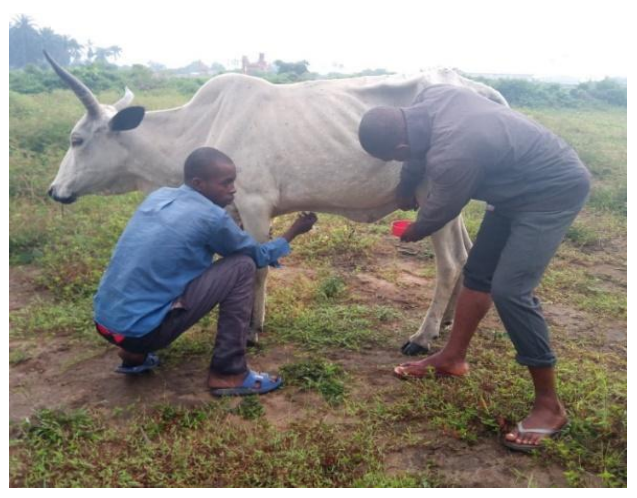

Fig 2: Collection of cow milk using plastic plate by a milker 
Akinjogunla et al./ Nig. J. Biotech. Vol. 37 Num. 1: 10-2- (June 2020)

Table 3: Physical Examination of Yoghurt Containers for Labelling Compliance

\begin{tabular}{cccc}
\hline & \multirow{2}{*}{$\begin{array}{c}\text { No of Yoghurts } \\
\text { Collected }\end{array}$} & $\begin{array}{c}\text { Yes } \\
\text { No }(\%)\end{array}$ & $\begin{array}{c}\text { No } \\
\text { No }(\%)\end{array}$ \\
\hline NAFDAC Number & 35 & $25(71.4)$ & $10(28.6)$ \\
Production Date & 35 & $33(94.3)$ & $2(5.7)$ \\
Expiry Date & 35 & $30(85.7)$ & $5(14.3)$ \\
Batch Number & 35 & $28(80.0)$ & $7(20.0)$ \\
Manufacturer's Address & 35 & $25(71.4)$ & $10(28.6)$ \\
Product's Name & 35 & $35(100)$ & $0(0.0)$ \\
Volume & 35 & $33(94.3)$ & $2(5.7)$ \\
\hline
\end{tabular}

Key: NAFDAC: National Agency for Food and Drug Administration and Control; Values in parenthesis represent percentages

Table 4: Mean E. coli 0157 and Non-E. coli 0157 Counts of Raw Milk and Milk Products

\begin{tabular}{|c|c|c|c|c|c|c|c|}
\hline \multirow[b]{3}{*}{ Samples } & \multirow{3}{*}{$\begin{array}{cc} & \text { Number } \\
\text { of } & \text { Samples } \\
\text { Collected }\end{array}$} & \multicolumn{6}{|c|}{$\mathrm{CFU} / \mathrm{ml}$} \\
\hline & & \multicolumn{3}{|c|}{ E. coli 0157} & \multicolumn{3}{|c|}{ Non-E. coli 0157} \\
\hline & & Min & $\operatorname{Max}$ & $\overline{\text { mean } \pm} \mathrm{S} . \mathrm{D}$ & Min & $\operatorname{Max}$ & mean \pm S. $D$ \\
\hline Cow & 29 & $4.0 \times 10^{2}$ & $1.7 \times 10^{3}$ & $8.6 \pm 4.5 \times 10^{2 b}$ & $6.0 \times 10^{2}$ & $1.9 \times 10^{3}$ & $9.0 \pm 4.8 \times 10^{2 b}$ \\
\hline Goat & 47 & $5.0 \times 10^{2}$ & $1.2 \times 10^{3}$ & $7.4 \pm 2.4 \times 10^{2 b}$ & $9.0 \times 10^{2}$ & $2.0 \times 10^{3}$ & $1.1 \pm 1.0 \times 10^{3 c}$ \\
\hline Nono & 42 & $1.0 \times 10^{2}$ & $7.0 \times 10^{2}$ & $3.7 \pm 2.0 \times 10^{2 a}$ & $2.0 \times 10^{2}$ & $1.0 \times 10^{3}$ & $5.7 \pm 2.5 \times 10^{2 a b}$ \\
\hline Yoghurt & 35 & $1.0 \times 10^{2}$ & $5.0 \times 10^{2}$ & $2.3 \pm 1.9 \times 10^{2 a}$ & $1.0 \times 10^{2}$ & $9.0 \times 10^{2}$ & $3.8 \pm 2.8 \times 10^{2 a}$ \\
\hline
\end{tabular}

Key: S.D: Standard deviation; Min: Minimum; Max: Maximum; mean within the column followed by the different superscript letters are significant as determined by Duncan multiple range test $(P<0.05)$, CFU:

Colony Forming Units 
Table 5: Occurrence of $E$. coli Isolated from Raw Milk and Milk Products

\begin{tabular}{lcccc}
\hline & Sample & $\begin{array}{c}\text { No Collected } \\
\text { /Analyzed (\%) }\end{array}$ & $\begin{array}{c}\text { Nos. Positive of } E \\
\text { coli }(\%)\end{array}$ & $\begin{array}{c}\text { Percentage among } \\
\text { Positive Samples }\end{array}$ \\
\hline Raw Milk & Cow milk & $29(19.0)$ & $13(44.8)$ & 22.0 \\
\multirow{4}{*}{ Milk Products } & Goat milk & $47(30.7)$ & $22(46.8)$ & 37.3 \\
& Nono & $42(27.4)$ & $15(35.7)$ & 25.4 \\
& Yoghurt & $35(22.9)$ & $9(25.7)$ & 15.3 \\
& Total & $153(100)$ & $59(38.6)$ & 100 \\
\hline
\end{tabular}

Table 6: Occurrence of Typable and Non-typable E. coli Isolated from Raw Milk and Milk Products

\begin{tabular}{cccc}
\hline Sample & $\begin{array}{c}\text { No. of } E \text {. coli } \\
\text { isolated }\end{array}$ & $\begin{array}{c}\text { Typable } E \text {. coli } \\
\text { No }(\%)\end{array}$ & $\begin{array}{c}\text { Non-typable } E \text {. coli } \\
\text { No }(\%)\end{array}$ \\
\hline Cow milk & 13 & $11(84.6)$ & $2(15.4)$ \\
Goat milk & 22 & $19(86.4)$ & $3(13.6)$ \\
Nono & 15 & $11(73.3)$ & $4(26.7)$ \\
Yoghurt & 9 & $6(66.7)$ & $3(33.3)$ \\
Total & 59 & $47(79.7)$ & $12(20.3)$ \\
\hline
\end{tabular}

Table 7: Occurrence of E. coli Serotypes Isolated from Raw Milk and Milk Products

\begin{tabular}{|c|c|c|c|c|c|c|}
\hline $\begin{array}{l}\text { Bacterial } \\
\text { Isolate }\end{array}$ & Serotypes & $\frac{\text { Cow Milk }}{\text { No (\%) }}$ & $\frac{\text { Goat Milk }}{\text { No (\%) }}$ & $\frac{\text { Nono }}{\text { No }(\%)}$ & $\frac{\text { Yoghurt }}{\text { No (\%) }}$ & $\begin{array}{c}\text { Total } \\
\text { No }(\%)\end{array}$ \\
\hline \multirow{8}{*}{$\begin{array}{l}\text { E. coli } \\
(n=47)\end{array}$} & 0157 & $5(45.5)$ & $7(36.8)$ & $3(27.3)$ & $3(50.0)$ & $18(38.3)$ \\
\hline & 0125 & $2(18.2)$ & $4(21.1)$ & $2(12.2)$ & $1(16.7)$ & 9 (19.1) \\
\hline & 0111 & $1(9.0)$ & $2(10.5)$ & $1(9.0)$ & $0(0.0)$ & $4(8.5)$ \\
\hline & 026 & $2(18.2)$ & $2(10.5)$ & $1(9.0)$ & $2(33.3)$ & 7 (14.9) \\
\hline & 0103 & $0(0.0)$ & $3(15.8)$ & $3(27.3)$ & $0(0.0)$ & $6(12.8)$ \\
\hline & 0128 & $1(9.0)$ & $0(0.0)$ & $1(9.0)$ & $0(0.0)$ & $2(4.3)$ \\
\hline & 0145 & $0(0.0)$ & $1(5.3)$ & $0(0.0)$ & $0(0.0)$ & $1(2.1)$ \\
\hline & Total & $11(100)$ & $19(100)$ & $11(100)$ & $6(100)$ & $47(100)$ \\
\hline
\end{tabular}


Table 8: Occurrences of Verocytotoxins VTI- and VT2- Producing E. coli Serotypes from Raw milk and Milk Products

\begin{tabular}{cccccc}
\hline & & \multicolumn{2}{l}{$\begin{array}{l}\text { Verocytotoxin } \\
\text { Producers }\end{array}$} & & \multicolumn{1}{c}{$\begin{array}{c}\text { Non-Verocytotoxin } \\
\text { Producers }\end{array}$} \\
\cline { 3 - 5 } Serotypes & $\begin{array}{c}\text { No of } \\
\text { Isolates }\end{array}$ & $\begin{array}{c}\mathrm{VTI} \\
\mathrm{No}(\%)\end{array}$ & $\begin{array}{c}\mathrm{VT} 2 \\
\mathrm{No}(\%)\end{array}$ & $\frac{\mathrm{VT} 1 / \mathrm{VT} 2}{\mathrm{No}(\%)}$ & $\begin{array}{c}\text { Total } \\
\text { No } \%)\end{array}$ \\
\hline 0157 & 18 & $2(11.1)$ & $7(38.9)$ & $5(27.8)$ & $4(22.2)$ \\
0125 & 9 & $1(11.1)$ & $3(33.3)$ & $1(11.1)$ & $4(44.4)$ \\
0111 & 4 & $0(0.0)$ & $2(50.0)$ & $0(0.0)$ & $2(50.0)$ \\
026 & 7 & $1(14.3)$ & $3(42.9)$ & $0(0.0)$ & $3(42.9)$ \\
0103 & 6 & $1(16.7)$ & $2(33.3)$ & $1(16.7)$ & $2(33.3)$ \\
0128 & 2 & $0(0.0)$ & $1(50.0)$ & $0(0.0)$ & $1(50.0)$ \\
0145 & 1 & $1(100)$ & $0(0.0)$ & $0(0.0)$ & $0(0.0)$ \\
Total & 47 & $6(12.8)$ & $18(38.3)$ & $7(14.9)$ & $16(34.0)$ \\
\hline
\end{tabular}

\section{Discussion}

The level of hygienic practices of the milkers and the milking processes obtained via the administration of questionnaires revealed that 33.3 $\%$ milkers used plastic cups and plates for collection of raw milks, while $59.3 \%$ milkers used plastic bottles only. The use of plastic containers for collecting raw milk in this study corroborated the work of Duguma and Geert (2015) who reported that $92.6 \%$ milkers in Jimma collected milk using plastic containers. The occurrence of more male milkers $(70.4 \%)$ than female milkers $(29.6 \%)$ in this study substantiated the findings of Yitaye et al. (2008) who reported more male milkers than female milkers in Northwest Ethiopia but this differed from the results of Bereda et al. (2012) who reported that dairying offered more opportunities for females than males and made them to be closely involved in the dairy management in Ezha District of the Gurage Zone.

Twenty-three (23) milkers had no formal education, $7.4 \%$ had primary education, and $7.4 \%$ had secondary education, while none had University Education. Our findings agreed with the reports from Southwest Ethiopia by Bereda et al. (2014) where majority of the household heads (milkers) were between illiterate and primary school. The non-usage of towel to clean and dry udders of cows /goats after milking in this study differed from the findings of Zelalem and Faye (2006) who reported that in the Central Highlands of Ethiopia, dairy producers used common towels for drying udders. Duguma and Geert (2015) reported that only $13 \%$ milkers in Southwestern Ethiopia used towel to dry the udders of the animals and this differed from this study as none of the milkers used towel for drying and cleaning the udders.

The absence of NAFDAC registration number and other relevant information on some packages of the yoghurts indicated that they might not be duly registered and approved by the government regulating agency. The unavailability of manufacturers' addresses on the packages may presumably make the producers untraceable in case of disease outbreaks resulting from the consumption of the products. The percentage occurrences ( $\leq 44.8 \%$ ) of $E$. coli in these samples were in accordance with Fadel and Ismail (2009) and Okonkwo (2011) who reported $>20 \%$ E. coli in milk and milk products. The isolation rate of $E$. coli $\mathrm{O} 157$ in the raw cow milk (38.3\%) in this study was higher than $11 \%$ obtained by Sancak et al. (2015). The E. coli 0157 had the highest percentage occurrence $(38.3 \%)$, followed by $E$. coli 0125 , while 
E. coli 0145 had the lowest percentage occurrence in the samples. The high occurrence of E. coli 0157 obtained in this study was in consonance with the reports of Doyle et al. (2015).

The latex agglutination screening of $E$ coli serotypes from raw milk and milk products showed that $12.8 \%$ E. coliserotypes produced verocytotoxin VT1, $38.3 \% \quad E$. coli serotypes produced verocytotoxin VT2, while $14.8 \%$ E. coli serotypes were both verocytotoxin VT1- and VT2- producers. In this study, the milk products had verocytotoxigenic $E$. coli $\mathrm{O} 157$ and these findings were in agreement with reports from Canada and United States by Morgan et al. (1993) and Dorn (1995) in which VTEC 0157 were isolated from nono and yoghurts. The VTEC 0157 infections have been associated with the consumption of yoghurt (Morgan et al., 1993). The occurrence of VTEC O157 in raw milk and nono in this study is indicative of cross infection from apparently healthy dairy cows to the dairy products especially as they may not have been properly pasteurized. The isolation of VTEC 0125, 0111, 026 and 0145 in raw milk was similar to the findings of Muehlherr et al. (2003) who obtained 12 VTEC strains belonging to the non - 0157 VTEC from goat milk. This result indicated that goats can be a reservoir of non - O157 VTEC and the consumption of raw goat milk or milk products can pose health risk to consumers, especially in the light of the fact that the goat milk is recommended for children allergic to cow milk and also for persons with decreased immunity. The occurrence of VTEC in the unpasteurized milk shows that the milkers should be enlightened on the necessary sanitary practices to adopt during milking and also post-pasteurization contamination of milk products should be avoided.

\section{References}

Adwan, K., Abu-Hasan, N., Essawi, T. and Bdir, M. (2002): Isolation and characterisation of shiga toxigenic Escherichia coli strains from northern Palestine. J. Med. Microbiol., 51: 332 - 335.

Akinjogunla, O. J., Eghafona, N. O. and Ekoi, O. H. (2009). Diarrheagenic E. coli (DEC): Prevalence among in and ambulatory patients and susceptibility to antimicrobial chemo -therapeutic agents. J. Bacteriol. Res., 1(3): 34 - 38.

Altalhi, A. D. and Hassan, S. A. (2009). Bacterial quality of raw milk investigated by $E$. coli and isolates analysis for specific virulence -gene Markers. Food Control, 20: 913 - 917.
Bereda, A., Yilma, Z. and Nurfeta A (2014). Dairy production system and constraints in Ezha districts of the Gurage zone, southern Ethiopia. Glob. Vet., 12(2):181-186.

Bereda, A., Yilma, Z. and Nurfeta, A. (2012). Hygienic and microbial quality of raw whole cow's milk produced in Ezha district of the Gurage zone, southern Ethiopia. Wudpecker. J. Agric. Res., 1(11): 459 - 465.

Blanco, M., Blanco J. E., Blanco J., Mora A., Prado, C., Alonso, M. P., Mourino M., Madrid C., Balsalobre C., and Juarez, A. (1997): Distribution and characterization of faecal verocytotoxin-producing Escherichia coli (VTEC) isolated from healthy cattle. Vet Microbiol., 54: $309-319$.

Borgattaa, B., Kmet-Lunacekb, N. and Relloc, J. (2012). E. coli O104: H4 outbreak and haemolytic uraemic syndrome. Med. Intensiva.

Cheesbrough, M. (2006). District Laboratory Practice in Tropical Countries, Part II. Cambridge University pp. 19 - 110.

Doyle, M. M., Garcia, S., Bahati, E., K. and Nandi, S. (2015). Microbiological analysis of raw milk in Rwanda. Afr. J. Food Sci., 6: 141-143.

Duguma, B. and Geert, P. (2015). Assessment of dairy farmers' hygienic milking practices and awareness of cattle and milk-borne zoonoses in Ethiopia, Quality Management, 45:1-3

Dwight, C., Hirsh, M., James N. and Richard L. (2004). Veterinary Microbiology. 2nd Ed. Blackwell Publishing, pp: $61-68$.

Fadel, H.M. and Ismail, J. (2009). Prevalence and significance of $S$, aureus and Enterobacteriaceae species in selected dairy products and handlers. Int. J. Dairy Sci., 4: 100 - 108.

Griffin, P. M. and Tauxe, R. V. (1991). The epidemiology of infections caused by Escherichia coli 0157:H7, other enterohemorrhagic $E$. coli, and the associated hemolytic uremic syndrome. Epidemiol. Rev., 13: 60 - 98.

Harding, F. (1995), Compositional Quality. In: Harding, F. (Ed.). Milk Quality. Blackie Academic and Professional, Chapman and Hall, London. pp. $75-96$. 
Kumar, N., Taneja, A., Bharti, B. and Sharma, M. (2014). Characterization of shiga toxigenic Escherichia coli isolated from cases of diarrhea and haemolytic uraemic syndrome in north India. Indian J. Med. Res, 140: 778 - 784.

Lee, J., Reed, E., Shields, M., Spiegel, K., Farrell, L. and Sheridan, P. (2007). Phylogenetic analysis of shiga toxin 1 and shiga toxin 2 genes associated with disease outbreaks. BMC Microbiol., 7: 109-110.

Morgan, D., Newman, C. P., Hutchison, D. N., Walker, A. M., Rowe, B. and Majid, F. (1993). VTEC O157 infection associated with consumption of yoghurt. Epidemiol. Infect. 111, 181-188.

Muehlherr, J. E., Zweifel, C., Corti, S., Blanco, J. E. and Stephen, R. (2003). Microbiological quality of raw goats and ewes bluk-tank milk in Switzerland. Journal of Dairy Science, 86 (12): 3849- 3856.

Nataro, J. P. and Kaper, J. B. (1998). Diarrheagenic Escherichia coli. Clinical Microbiology Review, 11:142 - 201.

Okonkwo, O.I. (2011). Microbiological analyses and safety evaluation of nono: A fermented milk product consumed in most parts of northern Nigeria. Int. J. Dairy Sci., 6: 181-189.

Paton, J. C. and Paton, A. W. (1998). Pathogenesis and diagnosis of shiga toxin producing Escherichia coli infections. Clin. Microbiol. Rev., 11:450 - 479.

Perera, C., Clarke, M., Dykes G. and Fegan, N. (2015). Characterization of shiga toxigenic Escherichia coli $\mathrm{O} 157$ and Non $\mathrm{O} 157$ isolates from ruminant feces in Malaysia, Biomed. Res. Int., 54: 1 $-8$.

Pitkala, A., Haveri, M., Pyorala, S and Myllys, V. (2004). Bovine mastitis in Finland 2001 prevalence, distribution of bacteria and antimicrobial resistance. J. Dairy Sci., 87: 2433 - 2441.

Sancak, Y. C., Sanck, H., Isekeyici, H. and Durmaz, H. (2015). Presence of E. coli 0157 and 0157; H7 in raw milk. Bull. Vet. Inst. Pulawy, 59: 511-514.

Tarr, P. I. and Neil, M. A. (1996). Perspective Problem of non-O157 Shiga toxin (verocytotoxin)producing E. coli. J. Infect. Dis., 174: 1136 - 1139.

Tilden, J., Young, W., McNamara, A. M., Custer , C. and Boesel, B. (1996). A new route of transmission for Escherichia coli: infection from dry fermented Salami. AJPH, 86: 1142-1145.
Yitaye, A., Zollitsch, W., Wurzinger, M. and Azage, T. (2008). Characterization and analysis of the urban and Peri-urban dairy production systems in the north western ethiopian highlands. A thesis submitted to BOKU - University of Natural Resources and Applied Life Sciences, Vienna, Austria for the award of Doctor Rerum anturalium technicarum, Vienna, October 2008.

Zelalem, Y. and Faye, B. (2006). Handling and microbial load of cow milk and irgo-fermented milk collected from different shops and producers in central highlands of Ethiopia. Ethiopian J. Animal Prod., 6 (2): 67 - 82. 